\title{
Channeling Janus: The Birth of the West German State and Rebirth of the German Nation
}

\author{
JACK JACOVOU \\ University of New South Wales \\ j.jacovou@hotmail.com
}

\begin{abstract}
This essay will submit three arguments which will sustain this thesis respectively: 1) the incorporation of expellees, the expellee movement, and their irredentism which romanticised the Nazi period, saw a form political extremism rise as a direct consequence of the breakup of Germany after World War II $(W W I I)^{1}$; 2) the decline of the German Communist Party (KPD) and National Socialist German Workers' Party (NSDAP) reflected Germans becoming critical of the political extremism prevalent between the 1919 until $1945^{2}$; 3) influenced by both the War and German history wholistically, the Allies and Germans crafted a Basic Law (Grundgesetz) which embodied a strong parliamentary and federal system. ${ }^{3}$ With all this in mind, the first argument to highlight how Germany drew upon its history to craft new political institutions and a new culture, is the incorporation of the expellees and their irredentism.
\end{abstract}

To what extent did the Federal Republic of Germany founded in 1949 mark a new beginning, as opposed to a restoration or continuation of older German political traditions?

By and large, the Federal Republic of Germany (FRG) founded in 1949 represented a dramatic shift in German political culture and institutions. These were profoundly influenced by historical events, especially from the Weimar years to the end of the Allied Occupation. The Allied Occupation of Germany should not be underestimated in terms of having fostered a democratic political framework within the FRG. This should not discount the already changing attitudes of Germans towards democracy and freedom however, with the two working in parallel. 4 Ultimately, both strands of thought serve to reinforce the concept that the FRG drew upon German history to establish a political system that would avoid future conflict. This essay will argue that

\footnotetext{
${ }^{1}$ Andrew Demshuk, The Lost German East: Forced Migration and the Politics of Memory, 1945-1970. (New York: Cambridge University Press, 2012), 106.; Daniel E. Rogers, "Transforming the German Party System: The United States and the Origins of Political Moderation, 1945-1949". The Journal of Modern History 65, no. 3 (2001): 525. 2 Rogers, "Transforming the German Party System: The United States and the Origins of Political Moderation, 1945-1949”, 512-513.

3 Hans G. Gnodtke, "Sixty Years of the German Basic Law (Constitution of the Federal Republic of Germany 1949) and Twenty Years of German Reunification - A Synopsis". James Cook University Law Review 16, no. 1 (2009): 13.; Marjorie Lamberti, "General Lucius Clay, German Politicians, And The Great Crisis During The Making Of West Germany's Constitution". German Politics and Society 27, no. 4 (Winter, 2009): 34, 36.; Edmund Spevack, "American Pressures on the German Constitutional Tradition: Basic Rights in the West German Constitution of 1949”. International Journal of Politics, Culture, and Society 10, no. 3 (1997): 415-416 4 Seymour R. Bolten, "Military Government and the German Political Parties". The Annals of the American Academy of Political and Social Science 267 (1950): 66.; R. S., "The West German Political Parties and Rearmament.". The World Today 9, no. 2 (1953): 53.
} 
from 1949, the FRG marked a new political era through its culture and institutions, to consciously distinguish itself from previous periods in German history which were turbulent and traumatic. Consequently, Germany's history directly informed the establishment of this political system, and also shifted the political mentality of Germans.

This essay will submit three arguments to support this thesis: 1) the incorporation of expellees, the expellee movement, and their irredentism which romanticised the Nazi period, saw a form of political extremism rise as a direct consequence of the breakup of Germany after World War II (WWII)5; 2) the decline of the German Communist Party (KPD) and National Socialist German Workers' Party (NSDAP) reflected increasing criticism of the political extremism prevalent between 1919 and $1945^{6} ; 3$ ) influenced by both the War and German history, the Allies with German input crafted the Basic Law (Grundgesetz) which embodied a strong parliamentary and federal system. ${ }^{7}$ With all this in mind, the first argument to highlight how Germany drew upon its history to craft new political institutions and a new culture, is the incorporation of the expellees and their irredentist attitudes.

Answering the question of how expellees were incorporated and how this was influenced by their displacement as a result of the War, this essay will refer to their precarious political situation. The German expellee movement emerged directly as a consequence of WWII and drew upon past events to influence the political system of West Germany. The social and cultural attitudes of these expellees were largely shaped by their nostalgia for the time immediately prior to their expulsion. ${ }^{8}$ As a consequence of the incorporation of many expellees as potential voters, mainstream political parties in Germany now had to appeal to this new demographic. ${ }^{9}$ However herein lay two problems: 1) the long-term political goals of the movement called for extra resources to be devoted to expellees during their 'stay' in Germany; 2) their ultimate goal was an eventual right to return 'home'.10 In this sense by 1949 the FRG was inexperienced and unprepared for how to address the concerns of this social group, and having to reconcile democratic values with representation would continue to be a problem.

Throughout the Occupation, expellees were prevented from forming political parties and expected to identify with mainstream parties; however efforts were made to bypass

\footnotetext{
5 Andrew Demshuk, The Lost German East: Forced Migration and the Politics of Memory, 1945-1970. (New York: Cambridge University Press, 2012), 106.; Daniel E. Rogers, "Transforming the German Party System: The United States and the Origins of Political Moderation, 1945-1949”. The Journal of Modern History 65, no. 3 (2001): 525 .

${ }^{6}$ Rogers, "Transforming the German Party System: The United States and the Origins of Political Moderation, 1945-1949", 512-513.

7 Hans G. Gnodtke, "Sixty Years of the German Basic Law (Constitution of the Federal Republic of Germany 1949) and Twenty Years of German Reunification - A Synopsis". James Cook University Law Review 16, no. 1 (2009): 13.; Marjorie Lamberti, "General Lucius Clay, German Politicians and the Great Crisis During the Making of West Germany's Constitution,' German Politics and Society 27, no. 4 (Winter, 2009): 34, 36.; Edmund Spevack, "American Pressures on the German Constitutional Tradition: Basic Rights in the West German Constitution of 1949," International Journal of Politics, Culture, and Society 10, no. 3 (1997): 415-416.

8 Jane Perry Clark Carey. "Political Organization of the Refugees and Expellees in West Germany". Political Science Quarterly 66, no. 2 (1951): 200.; Andrew Demshuk, The Lost German East: Forced Migration and the Politics of Memory, 1945-1970. (New York: Cambridge University Press, 2012), 105-106.

9 Demshuk, The Lost German East: Forced Migration and the Politics of Memory, 1945-1970, 73.; Joseph B. Schechtman, "Postwar Population Transfers in Europe: A Survey". The Review of Politics 15, no. 2 (1953): 167. ${ }^{10}$ Carey, "Political Organization of the Refugees and Expellees in West Germany", 212.; Daniel E. Rogers, "Transforming the German Party System: The United States and the Origins of Political Moderation, 1945-1949". The Journal of Modern History 65, no. 3 (2001): 524-525.; Schechtman, "Postwar Population Transfers in Europe: A Survey", 167.
} 
this by fielding independent tickets. ${ }^{11}$ Expellee efforts to enter the Bundestag in August 1949 were unsuccessful for this reason, as in no state were they able to enter the statewide party lists. ${ }^{12}$ It should be noted that the Allies permitted the formation of expellee associations, but these could not be religious, unionised, or professional. ${ }^{13}$ Thus there was some element of lobbying allowed for expellees, however this was not extended to equal political representation. Clearly this seismic shift in the political constituency of Germany was completely alien, but was a direct consequence of WWII and the political culture of previous German Reichs.

If we delve deeper into the reasons for expellees' desire to return to their original homelands however, it is clear that they faced discrimination from German nationals. Many of the difficulties faced by the expellees could be attributed to the economic strain integrating them put on each state. ${ }^{14}$ For instance, "[t]he western, Rhineland provinces... proved very reluctant to absorb the refugees from their overcrowded camps in Schleswig-Holstein, Lower Saxony, and Bavaria". ${ }^{15}$ Furthermore, the dramatic reduction in their quality of life led expellees to seek comfort in nostalgia for their former homelands. This nostalgia often overlapped with the Nazi period. ${ }^{16}$ Nevertheless, this phenomenon was more nuanced, with expellees "yearning for supposed 'German' traits of order, cleanliness, and a sophisticated culture", but not necessarily Nazism. ${ }^{17}$ Thus as a result of their dispossession, the expellees became socially and politically isolated in West Germany by 1949, leaving the German political system at a loss on how to effectively integrate them. In this sense, it is impossible to ignore the role Nazism played as regards the social, political, and cultural attitudes of these people, and how these attitudes would interact and come into conflict with the West German state and political framework.

The challenges posed by the expellees and the expellee movement represented new stumbling blocks for the young FRG. Expellees were socially and politically isolated from mainstream German society and faced systemic economic disadvantage upon their resettlement. Their social and political attitudes were largely influenced by a nostalgic association the Nazi years with happiness and prosperity, and their position as expellees stemming from their dispossession following WWII. Clearly past events shaped the new ways in which West Germans had to operate their political system and state apparatus to cater for this new demographic.

The second issue this essay will address is to demonstrate how West Germany was founded on new political beginnings informed by its past, exempliefied by the decline of the KPD and NSDAP, which reflected Germans becoming critical of the political extremism prevalent between 1919 and 1945.

\footnotetext{
${ }^{11}$ Carey, "Political Organization of the Refugees and Expellees in West Germany", 197-198.; Rogers,

"Transforming the German Party System: The United States and the Origins of Political Moderation, 1945-1949", 524 .

${ }^{12}$ Jane Perry Clark Carey. "Political Organization of the Refugees and Expellees in West Germany". Political

Science Quarterly 66, no. 2 (1951): 197.

13 Ibid.

14 Andrew Demshuk, The Lost German East: Forced Migration and the Politics of Memory, 1945-1970. (New

York: Cambridge University Press, 2012), 106, 109-110.; R. S., "The West German Political Parties and

Rearmament.". The World Today 9, no. 2 (1953): 58-59.

15 R. S., "The West German Political Parties and Rearmament.", 58-59.

${ }^{16}$ Demshuk, The Lost German East: Forced Migration and the Politics of Memory, 1945-1970, 105-106.

17 Ibid., p. 106-107.
} 
The decline of the KPD and NSDAP, throughout the Occupation and by 1949, presents the best example as to how Germany marked a new political beginning by being informed by its experience with political extremism. Broadly speaking, this decline in support was due to a variety of factors including, but not limited to: 1) the Allied regulation of political parties $\left.{ }^{18} ; 2\right)$ the memory of war in which the Nazis discredited the far-right and the USSR discredited the KPD ${ }^{19} ; 3$ ) electoral thresholds which prevented marginal parties from being able to enter parliaments. ${ }^{20}$ In support of the concept that the KPD and NSDAP had lost their appeal to German voters, the combined vote of the parties' was 49.55\% in the November 1932 Reichstag elections, compared to the 1949 Bundestag elections where the KPD received $5.7 \%$ and by which point the NSDAP was already banned. ${ }^{21}$ In line with the theme of this essay, I will focus on the role of the Allies in influencing German political parties throughout the Occupation alone.

By and large, the Allied regulation of German political parties was not as oppressive as one might expect given the connotations of the term, "occupation". Several German political parties were permitted to operate so long as they were in accordance with each power's conceptualisation of democracy. ${ }^{22}$ The main aim of the Allied powers through this hands-off form of political party regulation was to foster an independent democratic German political system. ${ }^{23}$ The impact of this is clear however given that "under the guidance of [O]ccupation authorities, the pre-Nazi political pattern and behavior ha[d] been restored almost intact". ${ }^{24}$ In recognition of their approach, the only criteria a party had to fulfil to be legal was to be representative, elective, democratic, and discursive. ${ }^{25}$ Further, the only party that the Americans allowed and then later permanently banned was the Bavarian Monarchist Party (BHKP). ${ }^{26}$ In this regard, it is clear that through a combination of external influence and regulation by the Allies, and as a result of Germans wanting to develop an independent democracy, the political system of the FRG was established by 1949. ${ }^{27}$

While this aspect of the Allied regulation of German political parties could be described as negative freedom for the German political system, there were some elements of the occupation in which the German political system encountered positive discrimination. As a consequence of having to govern the Occupation Zones in tandem with the USSR, the US tolerated the KPD, and later Socialist Unity Party (SED) more than one would expect. Besides aid and travel facilities for non-communist parties increasing, by 1948

\footnotetext{
${ }^{18}$ Seymour R. Bolten, "Military Government and the German Political Parties". The Annals of the American Academy of Political and Social Science 267 (1950): 55.; Daniel E. Rogers, "Transforming the German Party System: The United States and the Origins of Political Moderation, 1945-1949". The Journal of Modern History 65, no. 3 (2001): 518.

19 Rogers, "Transforming the German Party System: The United States and the Origins of Political Moderation, 1945-1949”, 513.

${ }^{20}$ Ibid.

21 "Bundestag election 1949 - The Federal Returning Officer", The Federal Returning Officer, 2018.

<https://www.bundeswahlleiter.de/en/bundestagswahlen/1949.html>. Accessed 5 May 2018.; "Das Deutche Reich Reichstagswahl November 1932”, Andreas Gonschior, 2005.

<http://www.gonschior.de/weimar/Deutschland/RT7.html>. Accessed 5 May 2018.

22 Bolten, "Military Government and the German Political Parties", 55.

23 R. S., "The West German Political Parties and Rearmament.". The World Today 9, no. 2 (1953): 53.

24 Seymour R. Bolten, "Military Government and the German Political Parties". The Annals of the American Academy of Political and Social Science 267 (1950): 66.

25 Ibid., p. 55.

${ }^{26}$ Daniel E. Rogers, "Transforming the German Party System: The United States and the Origins of Political

Moderation, 1945-1949”. The Journal of Modern History 65, no. 3 (2001): 520.

27 Ibid., p. 518.; R. S., "The West German Political Parties and Rearmament.", 53.
} 
there were no legal restrictions imposed on the KPD. ${ }^{28}$ Ultimately, "the pragmatism of the American approach toward political activities made possible a healthy flexibility adaptable to changing situations". ${ }^{29}$ Having said this, in line with the United Kingdom (UK) and France, the US did not permit the KPD and SPD to merge as the SED had in the East unless it was democratically ratified, which, given Social Democratic opposition, was not likely to occur. ${ }^{30}$ Undoubtedly, the collapse of the KPD and NSDAP during the Occupation fundamentally shaped the West German political system and was in direct response to the events of the Weimar Republic, Nazi rule, and WWII. The final component of German history this essay will use to highlight how Germany was founded on new political beginnings by reflecting on its past, is that of the crafting of the West German Basic Law.

The West German Basic Law was the founding document of the West German state and supposedly embodied the values of West Germans, projecting these to the international community. This document is the best tangible evidence for how West Germany's politics was founded on new beginnings influenced by its past. In this, it is important to remember that given the then view that the FRG was a transitory state, the Basic Law was also considered a transitory "constitution". ${ }^{31}$ Significantly however, several checks on power were included to prevent the consolidation of power into one role as had happened under Hitler. ${ }^{2}$ Hence the rationale for including these changes, and the role they served to play in light of Germany's experience with Nazism, will now be analysed.

The main purpose for creating the West German Basic Law in this way was due to the need for Germans to independently establish democratic institutions to prevent a repeat of the Weimar and Nazi years. 33 Compared to the constitution of the Weimar Republic, the West German Basic Law was crafted with strong protections against the consolidation of power in mind. For instance, from 1930, three years before Hitler became Chancellor, the use of Article 48 bypassed parliamentary approval and allowed President Hindenburg to rule by decree.34 In contrast, the West German Presidency was a ceremonial role, and under the parliamentary system, the Chancellor was always held accountable to the Bundestag, and to a lesser extent voters. 35 In support of this

\footnotetext{
${ }^{28}$ Seymour R. Bolten, "Military Government and the German Political Parties". The Annals of the American Academy of Political and Social Science 267 (1950): 59.; Daniel E. Rogers, “Transforming the German Party System: The United States and the Origins of Political Moderation, 1945-1949”. The Journal of Modern History 65, no. 3 (2001): 528.

29 Bolten, "Military Government and the German Political Parties", 56.

3o Rogers, "Transforming the German Party System: The United States and the Origins of Political Moderation, 1945-1949", 529-530.

${ }^{31}$ Hans G. Gnodtke, "Sixty Years of the German Basic Law (Constitution of the Federal Republic of Germany 1949) and Twenty Years of German Reunification - A Synopsis". James Cook University Law Review 16, no. 1 (2009): 7 .

$3^{2}$ Ibid., p. 13.; Edmund Spevack, “American Pressures on the German Constitutional Tradition: Basic Rights in the West German Constitution of 1949”. International Journal of Politics, Culture, and Society 10, no. 3 (1997): 415-416.

33 Gnodtke, "Sixty Years of the German Basic Law (Constitution of the Federal Republic of Germany 1949) and Twenty Years of German Reunification - A Synopsis", 6.; Marjorie Lamberti, "General Lucius Clay, German Politicians, And The Great Crisis During The Making Of West Germany's Constitution". German Politics and Society 27, no. 4 (Winter, 2009): 34.; Spevack, "American Pressures on the German Constitutional Tradition: Basic Rights in the West German Constitution of 1949", 419.

34 Gnodtke, "Sixty Years of the German Basic Law (Constitution of the Federal Republic of Germany 1949) and Twenty Years of German Reunification - A Synopsis", 13. 35 Ibid.
} 
idea that the West German Basic Law was made in response to Hitler's rise to power, Spevack notes that:

[t]he Germans involved in the shaping of the Grundgesetz had themselves experienced the almost complete destruction of western categories of individual rights during the period of Nazi rule and of World War II. On one hand, they were witnesses to wartime situations under the rule of fascism which should be avoided at all cost in the future. On the other hand, in 1949 they wished to salvage as much as possible the positive image which the German legal and political traditions had once enjoyed in the world. 36

In conjunction with the German push for a new reformed basic law/constitution, the Allies were also of vital influence in the formation of the West German Basic Law. That said, this should not imply that the Allies necessarily agreed on everything, and what shape the Basic Law should take.

While the Basic Law did ultimately enshrine a federal West German state, as was advocated by the British and Americans, the French in contrast wanted a confederation with the aim of keeping Germany weak. 37 Further, while drafting the Basic Law, Saarland was still French and Germans wanted Article 23 included to be able to incorporate new German states at a later date. $3^{8}$ Clearly these two factors of German history during the Occupation directly influenced the structure of the FRG by 1949 and beyond (thinking of Saarland and later East Germany). While there was some disagreement between the Allies regarding how West Germany would be structured, for them, a strong West German state would act as a bulwark against communism. 39 Ultimately the creation of the West German Basic Law definitively laid the foundations for a fundamentally new German state as a direct result of events that occurred throughout the Weimar, Nazi and Occupation periods. This is clearly demonstrated through the establishment of a parliamentary democracy and a federal republic in direct contrast to the Weimar and Nazi rule by decree, and later unitary totalitarian state.

Undoubtedly, events between 1919 and 1949 led Germany to engage in a process of reimagining its political institutions and culture in terms of how the state was organised and how its citizens operated within this framework. Even beforehand, however, with reference to the expellees, German history and culture played a large role in determining political and social interactions throughout the Allied Occupation of Germany and in the establishment of West Germany in 1949. With these factors in mind, it is not hard to see how the political institutions and culture of West Germany, at its very foundations, were widely informed by Germany's history and prior experience with politics.

\footnotetext{
${ }^{36}$ Edmund Spevack, "American Pressures on the German Constitutional Tradition: Basic Rights in the West German Constitution of 1949”. International Journal of Politics, Culture, and Society 10, no. 3 (1997): 419. 37 Marjorie Lamberti, "General Lucius Clay, German Politicians and the Great Crisis during the Making of West Germany's Constitution". German Politics and Society 27, no. 4 (Winter, 2009): 26.

${ }^{38}$ Hans G. Gnodtke, "Sixty Years of the German Basic Law (Constitution of the Federal Republic of Germany 1949) and Twenty Years of German Reunification - A Synopsis". James Cook University Law Review 16, no. 1 (2009): 11.

39 Ibid., p. 7, 13.; Edmund Spevack, "American Pressures on the German Constitutional Tradition: Basic Rights in the West German Constitution of 1949”. International Journal of Politics, Culture, and Society 10, no. 3 (1997): 419.
} 
My analysis of the German expellees, the expellee movement and their irredentism, and the political disadvantages they faced, have served to highlight the extent to which their social, cultural, and political attitudes, were influenced by a nostalgic association with the period surrounding Nazi rule. This longing to return home forced the FRG to find new ways to address the political desires of this group who were echoing demands for a return to older social, cultural, and political traditions, which they were nostalgic for. 40 Through the lens of the decline of German political extremism during the Occupation period, this being the decline of the KPD and NSDAP, it is clear that West Germans were heavily influenced by the inherent instability of the Weimar Republic and Nazi rule. These attitudes were reinforced by the Allies during the Occupation and so it would seem that a rejection of political extremism would have been an inevitable fate of a new Allied influenced German state. ${ }^{41}$ Clearly in this regard, West Germany was founded on new political beginnings through an informed rejection of older political traditions: communism and Nazism. ${ }^{2}$ Finally, the crafting of the West German Basic Law was directly influenced by the Germans and Allies alike, where both parties desired to create a strong independent Germany that would never again succumb to political extremism, nor cause conflict. By looking back to the Weimar and Nazi years and vehemently rejecting the notion of a presidential republic, confederation, and unitary state, the framers of the Basic Law were able to ensure that power could never again be consolidated into one position, and that the FRG would be a strong independent bulwark against communism. ${ }^{43}$ Despite all this, more research must be completed as to the extent of the Allied involvement in the development of new political institutions, and a new political culture for West Germany during the Occupation.

If anything, this essay has highlighted the difficulties Germans faced throughout the Occupation as to what their future state would look like. These discussions and decisions were taken under the guidance of the Allies, but this should not discount their own drive to reform German political institutions and culture. Despite this, events that took place during the Occupation highlight the difficulties politicians and citizens face in having to acknowledge or ignore specific elements of their culture and history. Questions arise in this regard: 1) by whose authority can this decision occur; 2) are there any protected elements of culture and history; 3) is it ethically responsible to pick and choose? Ultimately this essay has focused exclusively on Germany, however these three questions remain existential issues relevant to all societies.

\footnotetext{
$4^{40}$ Jane Perry Clark Carey. "Political Organization of the Refugees and Expellees in West Germany". Political Science Quarterly 66, no. 2 (1951): 212.; Andrew Demshuk, The Lost German East: Forced Migration and the Politics of Memory, 1945-1970. (New York: Cambridge University Press, 2012), 105-106.; Daniel E. Rogers, "Transforming the German Party System: The United States and the Origins of Political Moderation, 1945-1949". The Journal of Modern History 65, no. 3 (2001): 525.; Joseph B. Schechtman, "Postwar Population Transfers in Europe: A Survey". The Review of Politics 15, no. 2 (1953): 167.

${ }^{41}$ Seymour R. Bolten, "Military Government and the German Political Parties". The Annals of the American Academy of Political and Social Science 267 (1950): 56, 58-61.; Rogers, "Transforming the German Party System: The United States and the Origins of Political Moderation, 1945-1949”, 518.

42 "Bundestag election 1949 - The Federal Returning Officer", The Federal Returning Officer, 2018.

<https://www.bundeswahlleiter.de/en/bundestagswahlen/1949.html>. Accessed 5 May 2018.; "Das Deutche Reich Reichstagswahl November 1932", Andreas Gonschior, 2005.

<http://www.gonschior.de/weimar/Deutschland/RT7.html>. Accessed 5 May 2018.

43 Hans G. Gnodtke, "Sixty Years of the German Basic Law (Constitution of the Federal Republic of Germany 1949) and Twenty Years of German Reunification - A Synopsis". James Cook University Law Review 16, no. 1 (2009): 7.; Marjorie Lamberti, "General Lucius Clay, German Politicians and the Great Crisis during the Making of West Germany's Constitution". German Politics and Society 27, no. 4 (Winter, 2009): 26.
} 


\section{Bibliography}

Federal Returning Officer, "Bundestag election 1949 - The Federal Returning Officer," The Federal Returning Officer, 2018.

<https://www.bundeswahlleiter.de/en/bundestagswahlen/1949.html >. Accessed 5 May 2018.

Bolten, Seymour R. "Military Government and the German Political Parties". The Annals of the American Academy of Political and Social Science 267 (1950): 55-67.

Carey, Jane Perry Clark. "Political Organization of the Refugees and Expellees in West Germany". Political Science Quarterly 66, no. 2 (1951): 191-215.

Demshuk, Andrew. The Lost German East: Forced Migration and the Politics of Memory, 1945-1970. New York: Cambridge University Press, 2012.

Gnodtke, Hans G. "Sixty Years of the German Basic Law (Constitution of the Federal Republic of Germany 1949) and Twenty Years of German Reunification - A Synopsis". James Cook University Law Review 16, no. 1 (2009): 5-19.

Lamberti, Marjorie. "General Lucius Clay, German Politicians and the Great Crisis during the Making of West Germany's Constitution". German Politics and Society 27, no. 4 (Winter, 2009): 24-50.

Rogers, Daniel E. “Transforming the German Party System: The United States and the Origins of Political Moderation, 1945-1949". The Journal of Modern History 65, no. 3 (2001): 512-541.

S. R. "The West German Political Parties and Rearmament." The World Today 9, no. 2 (1953): 53-64.

Schechtman, Joseph B. "Postwar Population Transfers in Europe: A Survey". The Review of Politics 15, no. 2 (1953): 151-178.

Spevack, Edmund. "American Pressures on the German Constitutional Tradition: Basic Rights in the West German Constitution of 1949”. International Journal of Politics, Culture, and Society 10, no. 3 (1997): 411-436.

Gonschior, Andreas. "Die Deutsche Reich Reichstagswahl November 1932”, 2005. Gonschior.de, 2005. < http://www.gonschior.de/weimar/Deutschland/RT7.html>. Accessed 5 May 2018. 